\title{
IRIS - An Internet Based Intervention as a Suitable Path to Addictive Substance Use Prevention and Counselling in Pregnancy? Beneficiary Profiles and User Satisfaction
}

\author{
IRIS - ein internetbasiertes Angebot als geeigneter Weg der Suchtmittelprävention und -beratung \\ in der Schwangerschaft? Nutzerinnenprofile und Anwenderzufriedenheit
}

Authors

Affiliations

\section{A. Stiegler ${ }^{1}$, H. Abele ${ }^{2}$, A. Batra ${ }^{1}$}

${ }^{1}$ Section for Addiction Medicine and Addiction Research, University Hospital Tübingen, University Department of Psychiatry and Psychotherapy, Tübingen, Germany

2 University Gynaecology Department, University Hospital Tübingen, Tübingen, Germany

Key words
pregnancy
alcohol
tobacco
internet
- prenatal prevention
Schlüsselwörter
- Schwangerschaft
- Alkohol
Tabak
Internet
pränatale Prävention

Deutsche Version unter: http://dx.doi.org/ $10.1055 / \mathrm{s}-0042-109867$

\section{received $\quad 4.1 .2016$ \\ revised 29.4.2016 \\ accepted 4.6.2016}

\section{Bibliography}

Dol http://dx.doi.org/ $10.1055 / \mathrm{s}-0042-109867$

Geburtsh Frauenheilk 2016; 76 : 1163-1171 c) Georg Thieme Verlag KG Stuttgart · New York ISSN 0016-5751

\section{Correspondence}

Dr. Anette Stiegler

University Hospital Tübingen University Department of

Psychiatry and Psychotherapy

Section for Addiction Medicine

and Addiction Research

Calwerstraße 14

72076 Tübingen

Germany

anette.stiegler@

med.uni-tuebingen.de

\section{Abstract \\ $\nabla$}

Alcohol or tobacco consumption in pregnancy can harm the unborn child. Counselling on this subject is therefore of major importance. The aim of the presented study was not only to develop an internet based, professionally e-mail accompanied platform for alcohol or tobacco consuming pregnant women ("IRIS Platform") but also to analyse the beneficiary profiles and investigate the practicability and acceptance of the platform among women and referring gynaecologists. The offer comprised three 12-week counselling programmes (alcohol, tobacco, combined consumption). Altogether 32 women registered within the recruitment period of 20 weeks, only 9 of them at the suggestion of gynaecologists. Thirty were enrolled. The average age was 31 years. Ten women were pregnant for the first time, 14 unplanned. Most of them were smokers $(n=29) .75 \%(n=12$ of 16) of them had smoked in the previous pregnancies, 5 of 16 women had suffered miscarriages. Six women completed the entire 12 week programme. The abstinence rate after 3 months was $\min .18 .5 \%$ (ITT) in the tobacco group, while in the alcohol programme 3 women achieved abstinence. Satisfaction was reported especially for the eCoach initiative. The results demonstrate that an internet-based service like IRIS can be a useful form of support for tobacco or alcohol consuming pregnant women. A particular challenge is the accessibility of the persons concerned and the form in which alcohol consuming pregnant women are approached in daily medical practice. The individual contact to the eCoach can be a decisive form of support and aid to motivation.

\footnotetext{
* Aus Gründen leichterer Lesbarkeit wird im nachfolgenden Text die maskuline Formulierung verwandt, wobei stets sowohl weibliche als auch männliche Personen gemeint sind.
}

\section{Zusammenfassung \\ $\nabla$}

Alkohol- oder Tabakkonsum in der Schwangerschaft kann das Ungeborene schädigen. Die Beratung Schwangerer zu diesem Thema ist daher von großer Bedeutung. Ziel der vorgestellten Studie war neben der Entwicklung einer internetbasierten, professionell durch E-Mail begleiteten Plattform für alkohol- oder tabakkonsumierende Schwangere („IRIS-Plattform“) eine Analyse der Nutzerinnenprofile und die Untersuchung der Umsetzbarkeit und Akzeptanz des Angebots bei Schwangeren und zuweisenden Frauenärzten*. Das Angebot umfasste 3 12-wöchige Beratungsprogramme (Alkohol, Tabak, kombinierter Konsum). Insgesamt registrierten sich im Rekrutierungszeitraum von 20 Wochen 32 Frauen, lediglich 9 davon nach Ansprache durch Frauenärzte. 30 wurden eingeschlossen. Das Durchschnittsalter betrug 31 Jahre. Zehn Frauen waren erstmalig schwanger, 14 ungeplant. Überwiegend waren es Raucherinnen ( $\mathrm{n}=29)$. 75\% ( $\mathrm{n}=12 / 16)$ davon hatten in den vorgehenden Schwangerschaften geraucht, 5 von 16 Frauen Fehlgeburten erlitten. Sechs Frauen durchliefen die gesamten 12 Programmwochen. Die Abstinenzquote nach 3 Monaten lag in der Tabakgruppe bei mind. 18,5\% (ITT), im Alkoholprogramm erreichten 3 Frauen eine Abstinenz. Zufriedenheit wurde vor allem für das E-Coach-Angebot berichtet. Die Ergebnisse belegen, dass ein internetbasiertes Angebot wie IRIS als Unterstützung für tabak- oder alkoholkonsumierende Schwangere sinnvoll sein kann. Eine besondere Herausforderung stellt einerseits die Erreichbarkeit Betroffener, andererseits die Ansprache alkoholkonsumierender schwangerer Frauen im Praxisalltag dar. Der individuelle Kontakt zum E-Coach kann eine entscheidende Unterstützungsmöglichkeit und Motivationshilfe darstellen. 


\section{Introduction}

$\nabla$

The consumption of legal addictive substances is widespread in the population [1]. Although various measures such as restrictions on advertising or prevention programmes and public relations work, price increases and increasing smoking cessation interventions by the healthcare professions have brought about a slight decrease in the consumption figures in both sexes and especially among minors, nevertheless about $24.5 \%$ of the adult population of Germany (about 20\% of the women and $29 \%$ of the men) still smoke [German Federal Statistical Office 2014]. 9.5 million Germans consume alcohol in hazardous amounts [2]. The risk group of pregnant consumers has been attracting increasing attention from political health policy makers in recent years, reflected among other things by the issue of a new version of the maternity record in 2012, awareness campaigns or the promotion of target group specific initiatives. Further efforts to improve prevention of substance consumption, cessation counselling or therapeutic support are still necessary, however, especially since most women who have smoked during pregnancy wish to receive a detailed or at least a short counselling interview on this topic, or alternatively also written information or even a smoker cessation course [3]. Only 7\% of the women did not wish to be addressed on the subject of smoking [3].

In pregnancy, considerable risks can be avoided by refraining from the use of addictive substances. For tobacco consumption in pregnancy, this may mean: the risk of a miscarriage decreases in proportion to the number of cigarettes not consumed per day [4]. Intrauterine dystrophy can be prevented [5-7]. The occurrence of placental complications (e.g. placenta previa) can be reduced [8]. The total of stillbirths and live births can also be considerably reduced by refraining from tobacco, especially in the second half of pregnancy $[9,10]$. Not least, the susceptibility of newborns to infectious diseases and medical conditions such as bronchial asthma also decreases [11,12].

Despite awareness of alcohol or tobacco related harm to their unborn child, not all pregnant women are motivated or able to completely relinquish tobacco or alcohol consumption. The reasons are many and complex and the problem cannot be understood as unicausal. It has therefore been considered how modern media could exert sustained influence on the consumption behaviour of pregnant women.

The internet offers the advantage of being available independent of location and time. Studies demonstrate that addiction specific internet based interventions can in principle bring about positive behavioural changes [13-15] and appear suitable for persons who would not normally use assistive and advisory services [14, 16-17]. Since pregnant women now inform themselves mainly through the internet $[18,19]$ a new counselling approach in the form of an individualised, risk adapted internet based intervention to reduce alcohol and tobacco consumption in pregnant women ("IRIS") should be trialled which offers the advantage of good time and cost economical accessibility as well as interactive, anonymous exchange in contrast to the disclosure situation of contact with physicians.

The core characteristic of this project sponsored as a pilot study by the German Federal Ministry of Health from 2011 to 2013 is the provision of an internet based counselling service for pregnant women aimed at overcoming obstacles in directly addressing pregnant women and creating an intervention adapted to the alcohol and tobacco consumption risk profile with a high degree of individualisation.
The study gave special consideration to evaluating the feasibility of such a project. It was also to be examined which subgroups utilise the offer and which sociodemographic and consumption related profiles the users exhibit.

\section{Subjects and Method \\ $\nabla$}

\section{Study design}

In a feasibility study (IRIS), affected pregnant women with abusive alcohol and/or tobacco consumption were to anonymously use the IRIS counselling platform.

\section{Target group}

The participants enrolled were adult pregnant women with at least one instance of consumption of alcohol and/or tobacco in pregnancy, adequate knowledge of German (to complete the questionnaires and read the programme contents) after giving consent to participate in the study.

\section{Recruitment}

Recruitment was to be performed by office-based gynaecologists $(n=35)$ and the Pregnancy Clinic of Tübingen University. Registration was done online after entering the code which allowed the referring physician to be identified.

\section{Intervention}

The 12-week initiative of the IRIS platform included three different programmes:

- tobacco consuming women received not only general information on tobacco consumption (psychoeducation) but also the possibility of participating in a cessation programme based on the programme "Non-smoker in 6 weeks" $[20,21]$. In contrast to other, non smoker-specific smoking cessation projects, the primary focus was placed on the earliest possible cessation of smoking.

- Women who consumed alcohol during pregnancy were given the opportunity to participate in a special alcohol counselling programme with informative and psychoeducative elements $[22,23]$. The focus was placed on immediate cessation of alcohol consumption. For alcohol dependent subjects, consultation with a medical specialist was recommended and contact addresses were provided.

- Women with alcohol and tobacco consumption received access to a combined programme uniting the elements of both initiatives.

The programme modules were passed through according to a prescribed plan with weekly contacts and included information articles and exercises. The materials were composed on the basis of established (psycho-)therapeutic techniques (including psychoeducation, motivating dialogues, relaxation techniques, anticraving skills, stress management, self-assertion and dealing with depression). Important elements could be repeated, a special relapse tool was continuously available. Materials were also provided for partners and three standardised reminder mails were sent to secure abstinence post partum. There was also a weekly, individualised, e-mail supported counselling session with a professional supporter. This eCoach actively contacted the participants once weekly with motivating e-mails. The aim of the anonymous exchange was to provide individual advice and motivation for abstinence. After three unread e-mails in succession, the coaching was terminated. 
Target parameters and evaluation strategies

Besides the beneficiary profiles with sociodemographic, gynaecological and psychiatric data, the Fagerström test for nicotine dependence (FTNA [24]) and the German version of the Alcohol Use Disorders Identification Test (AUDIT [25]) were used as established scales to record the characteristics of addictive substance consumption, and the ICD-10 criteria of dependence were applied [26]. The General Depression Scale [27]) was used to record currently present depressive symptoms. The catamnesis for recording addictive substance consumption was performed three months after completion of the intervention by e-mail.

Ten weeks after the start of the study, an intermediate survey on the recruitment progress was held among the gynaecologists.

\section{Statistical analysis}

The evaluation of the sociodemographic data and information about consumption behaviour and depressiveness recorded online was done descriptively. This was supplemented by univariate comparative investigations of active/inactive and tobacco abstinent/non abstinent participants. Twelve inactive and 11 active users were included in the analysis of degree of activity of tobacco consumers. Differences in the two groups were investigated for ordinal or interval scaled dependent variables with the Mann-Whitney U test, comparisons of categorical data were performed with $X^{2}$ tests.

The intermediate survey of gynaecologists for recruitment progress was evaluated descriptively.

\section{Results}

\section{$\nabla$}

\section{Registration figures and inclusions}

In a period of 20 weeks, 32 women registered on the platform, nine of them recruited by the gynaecologists. The other women became aware of the initiative spontaneously. In which manner this occurred was not recorded. Thirty women fulfilled the inclusion criteria, two were excluded (no alcohol or tobacco consumption and/or not pregnant).

Assignment to the counselling arms tobacco, alcohol or combined consumption was based on inclusion questions. The largest proportion consisted of smoking pregnant women $(n=25)$, four pregnant women participated in the combined programme, one in the alcohol programme.

The questions on consumption behaviour were answered by 29 of the 30 women enrolled in the study.

\section{Pregnant smoking women}

26 smoking women fulfilled the diagnostic criteria of tobacco dependence according to ICD- 10 . The mean point score in the FTNA represents moderately pronounced dependence. On average, the women commenced regular tobacco consumption from 16 years of age. On a scale of $0-10$ they were asked to describe their attitude to their smoking behaviour ( 1 = I like smoking without pangs of conscience, $10=\mathrm{I}$ smoke frequently with a bad conscience) and with the aid of the Smoking Abstinence Self-Efficacy Scale (SER) rated how confident they were of being able to cease smoking in certain temptation situations $(1=$ not at all confident to $5=$ extremely confident) (see $\mathbf{O}$ Table $\mathbf{1}$ ).

Many participants had already previously attempted to stop smoking $(n=19)$, for most of those questioned the last smokingfree interval was more than one year previously $(n=12)$. Reasons
Table 1 Comparison of tobacco related consumption characteristics of the IRIS participants in the tobacco $(\mathrm{T})$ and combined programme (AT).

\begin{tabular}{|c|c|c|}
\hline & $T(n=24)$ & AT $(n=4)$ \\
\hline $\begin{array}{l}\text { Presence of tobacco dependence } \\
\text { according to ICD-10 }\end{array}$ & $n=22$ & $n=4$ \\
\hline ICD-10 sum score (MV) for tobacco & 3.96 (SD 1.27) & 4.25 (SD 1.26) \\
\hline Sum value in FTNA (MV) & $\begin{array}{l}4.79 \text { (range } \\
4-6 . \text { SD 1.50) }\end{array}$ & $\begin{array}{l}4.5 \text { (range } \\
2-7, \text { SD } 1 \text { ) }\end{array}$ \\
\hline Age on smoking first cigarette (MV) & 14.5 & 14.5 \\
\hline $\begin{array}{l}\text { Bad conscience on smoking } \\
\text { (scale } 1-10, \mathrm{MV} \text { ) }\end{array}$ & 6.58 & 7.5 \\
\hline SER (scale 1-10, MV) & 2.97 & 2.44 \\
\hline
\end{tabular}

SER: Smoking Abstinence Self-Efficacy Scale; MV: mean value; SD: standard deviation

for reverting were stress and desire for a cigarette/craving. Further consumption characteristics are listed in $\bullet$ Table 2.

\section{Pregnant alcohol consumers}

One of the $n=5$ alcohol consumers showed dependency according to the ICD-10 criteria. Since medical treatment for addiction was being given simultaneously, she was not excluded as a participant. Three of the persons questioned had already attempted successfully to relinquish alcohol in the past. A recommendation to abandon alcohol had been given by the physician to three participants. Two of five stated that the partner drank alcohol regularly and in a manner that created problems. Four women expected support from their partner in abandoning alcohol.

\section{Sociodemographic, pregnancy-related} and psychiatric participant profiles

26 women made statements at the baseline interview. A survey of the answers is given in 0 Table 3 . It should be emphasised that three-quarters of the women had smoked during previous pregnancies (12 of 16), just under half also during breast feeding $(\mathrm{n}=8)$.

\section{Course}

In an interim survey it became clear that only $8.6 \%$ of the pregnant women approached by the 35 gynaecologists registered with IRIS ( $\mathrm{n}=9$ in 105 approaches). The majority of registrations were made directly on the IRIS homepage. Of 30 randomised pregnant women, two terminated participation after an abortion. The dropout rates were high especially in the first week of the programme $(n=6)$, in week 2 two, in week 3 three and in week 4 four women were inactive. From week 6 onwards, the number of participants remained stable. In the tobacco programme, five completed the 12-week counselling normally, the participants in the alcohol programme also concluded their participation normally, in the combined programme none of the three women remained until the end. One participant with alcohol dependence, assigned to the AT programme, reported on the consumption of seven alcoholic drinks in the first, and five in the second week of participation. Although she was then no longer active, she completed the course survey questions retrospectively and reported stable alcohol abstinence from week 3 onwards. One further participant of the AT programme remained until week 2 , in the course surveys after week 2 she reported alcohol abstinence. The participant in the alcohol programme without accompanying tobacco consumption reported abstinence weekly for the entire duration of the programme. 
Table 2 Tobacco consumption characteristics of the IRIS participants - an overview.

\begin{tabular}{|c|c|}
\hline & Tobacco consumers $(n=28)$ \\
\hline History of cessation attempts & $\begin{array}{l}\text { no }(9 ; 32 \%) \\
\text { yes }(19 ; 68 \%) \text {, of which } \\
\text { once }(5 ; 26 \%) \\
\text { - } 2-5 \text { times }(12 ; 63 \%) \\
=6-10 \text { times }(2 ; 11 \%)\end{array}$ \\
\hline - Type of last cessation attempt & $\begin{array}{l}\text { Picking-a-date method }(18 ; 95 \%) \\
\text { Reduced stepwise }(1 ; 5 \%)\end{array}$ \\
\hline $\begin{array}{l}\text { Duration of longest smoke-free } \\
\text { interval }\end{array}$ & $\begin{array}{l}\text { years }(7 ; 37 \%) \\
\text { months }(4 ; 21 \%) \\
\text { - weeks }(5 ; 26 \%) \\
\text { days }(3 ; 16 \%)\end{array}$ \\
\hline - Time of last smoke-free interval & $\begin{array}{l}\text { - } \text { in the last month }(3 ; 16 \%) \\
\text { - } 1-6 \text { months ago }(1 ; 5 \%) \\
\text { - } 6-12 \text { months ago }(3 ; 16 \%) \\
\text { - } 1-5 \text { years ago }(9 ; 47 \%) \\
\text { - more than } 5 \text { years ago }(3 ; 16 \%)\end{array}$ \\
\hline $\begin{array}{l}\text { Reason for relapse after last } \\
\text { smoking cessation (multiple } \\
\text { answer) }\end{array}$ & $\begin{array}{l}\text { - } \text { stress (14) } \\
\text { - desire/craving (9) } \\
\text { - because others were smoking (7) } \\
\text { - habit (4) } \\
\text { - } \text { after a good meal or in combina- } \\
\text { tion with alcohol (3) } \\
\text { - weight gain (0) }\end{array}$ \\
\hline Smoking behaviour beyond the day & $\begin{array}{l}\text { after waking and evenly distrib- } \\
\text { uted over the day }(18 ; 64 \%) \\
\text { sometimes not for a longer peri- } \\
\text { od and then again one after the } \\
\text { other }(10 ; 36 \%)\end{array}$ \\
\hline $\begin{array}{l}\text { Physician's recommendation to stop } \\
\text { smoking during pregnancy }\end{array}$ & $\begin{array}{l}\text { yes }(21 ; 75 \%) \\
\text { no }(7 ; 25 \%)\end{array}$ \\
\hline Partner wishes smoking cessation & $\begin{array}{l}\text { yes }(23 ; 82 \%) \\
\text { no }(5 ; 18 \%)\end{array}$ \\
\hline Smoking partner & $\begin{array}{l}\text { yes }(21 ; 75 \%) \\
\text { no }(7 ; 25 \%)\end{array}$ \\
\hline $\begin{array}{l}\text { Partner's support with smoking } \\
\text { cessation }\end{array}$ & $\begin{array}{l}\text { - certainly }(19 ; 68 \%) \\
\text { - rather yes }(3 ; 11 \%) \\
\text { - rather no }(6 ; 21 \%) \\
\text { - not at all }(0 ; 0 \%)\end{array}$ \\
\hline $\begin{array}{l}\text { Support of friends in stopping } \\
\text { smoking }\end{array}$ & $\begin{array}{l}\text { - certainly }(11 ; 39 \%) \\
\text { - rather yes }(9 ; 32 \%) \\
\text { r rather no }(8 ; 29 \%) \\
\text { - not at all }(0 ; 0 \%)\end{array}$ \\
\hline Friends predominantly smokers & $\begin{array}{l}\text { yes }(22 ; 79 \%) \\
\text { no }(6 ; 21 \%)\end{array}$ \\
\hline Friends' attitude to smoking & $\begin{array}{l}\text { rather positive }(23 ; 82 \%) \\
\text { rather negative }(5 ; 18 \%)\end{array}$ \\
\hline $\begin{array}{l}\text { Working colleagues predominantly } \\
\text { smokers }\end{array}$ & $\begin{array}{l}\text { yes }(12 ; 43 \%) \\
\text { no }(16 ; 57 \%)\end{array}$ \\
\hline $\begin{array}{l}\text { Working colleagues' attitude } \\
\text { to smoking }\end{array}$ & $\begin{array}{l}\text { - rather positive }(14 ; 50 \%) \\
\text { - rather negative }(14 ; 50 \%)\end{array}$ \\
\hline $\begin{array}{l}\text { Smoking cessation together with } \\
\text { partner/friends/working colleagues }\end{array}$ & $\begin{array}{l}\text { yes }(5 ; 18 \%) \\
\text { no }(23 ; 82 \%)\end{array}$ \\
\hline $\begin{array}{l}\text { Hope for advantages through } \\
\text { smoking cessation }\end{array}$ & $\begin{array}{l}\text { yes }(27 ; 96 \%) \\
\text { no }(1 ; 4 \%)\end{array}$ \\
\hline $\begin{array}{l}\text { Fear of disadvantages through } \\
\text { smoking cessation }\end{array}$ & $\begin{array}{l}\text { yes }(11 ; 39 \%) \\
\text { no }(17 ; 61 \%)\end{array}$ \\
\hline
\end{tabular}

\section{Catamnesis}

Three months after the end of the programme, all five reporting women stated that there had been a positive change in their tobacco consumption due to their participation in the IRIS programme. All stated that they had smoked less because of their participation, the four participants in the tobacco programme succeeded in stopping smoking completely during pregnancy. The two alcohol consumers reported that they had completely stopped consuming alcohol during pregnancy with the aid of the IRIS programme.

- Fig. 1 gives an overview of the course of the programme.

\section{Success of abstinence}

Summarising, the follow-up survey in the 3-month interval $(n=5)$ showed an abstinence rate in the tobacco programme of $18.5 \%$ (ITT). In the alcohol programme, 3 participants achieved abstinence during the course of the programme.

\section{Use of eCoaching}

The women used the opportunity to compose mail communications to the eCoach especially in the first week of the programme, over the entire period of the programme 52 messages were written by $\mathrm{n}=17$ participants, $\mathrm{n}=13$ wrote no messages.

\section{Satisfaction of participants}

Feedback concerning satisfaction with the initiative alone and the eCoaching in particular was given by $n=6$ IRIS users as part of the catamnesis ( Table 4).

\section{Comparative studies}

Active participants reported relatively often that they were assisted in their endeavours by their partner, but the effect was not significant $\left[X^{2}(2)=4.83\right.$, n.s.]. The same applies for the comparison of active and inactive beneficiaries at the time of the last smoking-free period (six months to 5 years vs. within the last six months or more than five years ago $)\left(X^{2}=7.87\right.$, n.s.). The working environment appears to have a further influence. The active IRIS users $\left(X^{2}=3.57\right.$, n. s.) had a circle of colleagues who are non-smokers with a rather negative attitude towards smoking. Moreover, participants tended more to remain more active if they reported prenatal complications $\left(X^{2}=4.29, p=0.038\right)$, preterm births $\left(X^{2}=4.29, p=0.038\right)$ or miscarriages $\left(X^{2}=3.35\right.$, n. s. $)$ in previous pregnancies.

Tobacco abstinent participants had experienced complications significantly more frequently in previous pregnancies $\left[X^{2}\right.$ $(1)=5.63, p=0.018]$. A negative attitude of the working environment to smoking $\left[X^{2}(1)=9.67, p=0.002\right]$ and a circle of colleagues consisting primarily of nonsmokers $\left[X^{2}(1)=11.24\right.$. $\left.p=0.001\right]$ also significantly influenced the success of smoking cessation.

Other than in the comparison of the active/inactive participants, the comparative analysis of the group of abstinent and non-abstinent subjects showed that significantly more of the tobacco abstinent women planned to stop together with another person (partner, friend, colleague) $\left[\mathrm{X}^{2}(1)=5.76, \mathrm{p}=0.016\right]$. Moreover, their partners more frequently tend to be nonsmokers $\left[X^{2}\right.$ $(1)=3.45$, n.s.) and abstinent women tend to engage more rarely in sporting activities $\left[\mathrm{X}^{2}(1)=3.65\right.$, n. s.], although these two aspects did not reach significance level. 
Table 3 Sociodemographic, psychiatric and pregnancy-related characteristics of the IRIS participants.

\begin{tabular}{|c|c|c|c|}
\hline & \multirow{2}{*}{$\begin{array}{l}\text { All participants } \\
n=26\end{array}$} & \multicolumn{2}{|c|}{ Divided according to programme } \\
\hline & & $T(n=21)$ & AT $/ A(n=5)$ \\
\hline \multicolumn{4}{|l|}{ Country of origin } \\
\hline - Germany & $25(96.2 \%)$ & $20(95.2 \%)$ & $5(100 \%)$ \\
\hline D Turkey & $1(3.8 \%)$ & $1(4.8 \%)$ & 0 \\
\hline Average age (years) & 31.1 (range 19-39, SD 4.56) & 30.6 (SD 4.9) & $33.2($ SD 1.64) \\
\hline \multicolumn{4}{|l|}{ Place of residence } \\
\hline Village or small town & $24(92.3 \%)$ & $20(95.2 \%)$ & $4(80 \%)$ \\
\hline C City & $2(7.7 \%)$ & $1(4.8 \%)$ & $1(20 \%)$ \\
\hline \multicolumn{4}{|l|}{ School-leaving qualification } \\
\hline - without school-leaving qualification & $1(3.8 \%)$ & $1(4.8 \%)$ & 0 \\
\hline becondary general school & $5(19.2 \%)$ & $4(19 \%)$ & $1(20 \%)$ \\
\hline D intermediate school & $14(53.8 \%)$ & $13(61.9 \%)$ & $1(20 \%)$ \\
\hline - general qualification for university entrance & $6(23.1 \%)$ & $3(14.3 \%)$ & $3(60 \%)$ \\
\hline \multicolumn{4}{|l|}{ Occupational training } \\
\hline - no completed training & $7(26.9 \%)$ & $7(33.3 \%)$ & 0 \\
\hline completed training & $14(53.8 \%)$ & $11(52.4 \%)$ & $3(60 \%)$ \\
\hline - completed university education & $5(19.2 \%)$ & $3(14.3 \%)$ & $2(40 \%)$ \\
\hline \multicolumn{4}{|l|}{ Occupational situation } \\
\hline undergoing training or employed & $22(84.6 \%)$ & $17(81 \%)$ & $5(100 \%)$ \\
\hline without employment & $4(15.4 \%)$ & $4(19 \%)$ & 0 \\
\hline \multicolumn{4}{|l|}{ Partnership } \\
\hline - permanent relationship, in which & $25(96.2 \%)$ & $20(95.2 \%)$ & $5(100 \%)$ \\
\hline$>$ married & $12(48 \%)$ & $10(50 \%)$ & $2(40 \%)$ \\
\hline single & $1(3.8 \%)$ & $1(4.8 \%)$ & 0 \\
\hline \multicolumn{4}{|l|}{ Housing situation } \\
\hline - with partner/family & $22(84.6 \%)$ & $18(85.7 \%)$ & $4(80 \%)$ \\
\hline > alone & $3(11.5 \%)$ & $2(9.5 \%)$ & $1(20 \%)$ \\
\hline flat-sharing community & $1(3.8 \%)$ & $1(4.8 \%)$ & 0 \\
\hline \multicolumn{4}{|l|}{ Regular hobbies or activities } \\
\hline yes & $11(42.3 \%)$ & $7(33.3 \%)$ & $4(80 \%)$ \\
\hline no & $15(57.7 \%)$ & $14(66.7 \%)$ & $1(20 \%)$ \\
\hline \multicolumn{4}{|l|}{ Sport/active movement } \\
\hline yes & $11(42.3 \%)$ & $7(33.3 \%)$ & $4(80 \%)$ \\
\hline no & $15(57.7 \%)$ & $14(66.7 \%)$ & $1(20 \%)$ \\
\hline \multicolumn{4}{|l|}{ Mental illness (past or current) } \\
\hline byes & $6(23.1 \%)$ & $4(19 \%)$ & $2(40 \%)$ \\
\hline no & $20(76.9 \%)$ & $17(81 \%)$ & $3(60 \%)$ \\
\hline \multicolumn{4}{|c|}{ Psychiatric-psychotherapeutic treatment (past or current) } \\
\hline yes & $7(26.9 \%)$ & $3(14.3 \%)$ & $4(80 \%)$ \\
\hline no & $19(73.1 \%)$ & $18(85.7 \%)$ & $1(20 \%)$ \\
\hline Depression (ADS), mean & 19 (range $13-37$, SD 6 ) & 19.1 (SD 6.4) & $18.8(S D 5.82)$ \\
\hline Week of pregnancy at registration, mean & 17 (range 4-35, SD 9.18) & 17.38 (SD 9.93) & $17.2(S D 5.76)$ \\
\hline Weeks, known since pregnancy, mean & $8.96($ SD 6.79$)$ & $8.43($ SD 7.25$)$ & $11.2($ SD 5.76$)$ \\
\hline \multicolumn{4}{|l|}{ Current pregnancy unplanned } \\
\hline yes & $14(53.8 \%)$ & $11(52.4 \%)$ & $3(60 \%)$ \\
\hline no & $12(46.2 \%)$ & $10(47.6 \%)$ & $2(40 \%)$ \\
\hline \multicolumn{4}{|l|}{ Number of previous pregnancies } \\
\hline - First pregnancy & $10(38.5 \%)$ & $6(28.6 \%)$ & $4(80 \%)$ \\
\hline - 1 or more & $16(61.5 \%)$ & $15(71.4 \%)$ & $1(20 \%)$ \\
\hline Number of children (16) & 16 & 15 & 1 \\
\hline > 1 child & $9(56.25 \%)$ & $8(53.3 \%)$ & $1(100 \%)$ \\
\hline - 2 children & $5(31.25 \%)$ & $5(33.3 \%)$ & 0 \\
\hline > 4 children & $1(6.25 \%)$ & $1(6.7 \%)$ & 0 \\
\hline not usable (reported: 0 ) & $1(6.25 \%)$ & $1(6.7 \%)$ & 0 \\
\hline Complications in previous pregnancies (16) & 16 & 15 & 1 \\
\hline yes, of which & $12(75 \%)$ & $12(80 \%)$ & 0 \\
\hline prenatal complications & $3(25 \%)$ & $3(25 \%)$ & 0 \\
\hline - perinatal complications & $1(8.3 \%)$ & $1(8.3 \%)$ & 0 \\
\hline miscarriage & $5(41.7 \%)$ & $5(41.7 \%)$ & 0 \\
\hline preterm birth & $3(25 \%)$ & $3(25 \%)$ & 0 \\
\hline no & $4(25 \%)$ & $3(20 \%)$ & $1(100 \%)$ \\
\hline
\end{tabular}


Table 3 Sociodemographic, psychiatric and pregnancy-related characteristics of the IRIS participants. (Continued)

\begin{tabular}{llll} 
& All participants & \multicolumn{2}{c}{ Divided according to programme } \\
Consumption in previous pregnancies (16) & $\mathbf{n = 2 6}$ & $\mathbf{T}(\mathbf{n = 2 1 )}$ & $\mathbf{A T} / \mathbf{A}(\mathbf{n}=\mathbf{5})$ \\
\hline tobacco & 16 & $11(73.3 \%)$ & 1 \\
- alcohol & $12(75 \%)$ & 0 & $1(100 \%)$ \\
- no consumption & 0 & $4(26.7 \%)$ & 0 \\
\hline Consumption in breast-feeding periods (16) & $4(25 \%)$ & 15 & 0 \\
\hline tobacco & 16 & $7(46.7 \%)$ & 1 \\
- alcohol & $8(50 \%)$ & 0 & $1(100 \%)$ \\
- no consumption & 0 & $7(46.7 \%)$ & 0 \\
- no breast-feeding & $7(43.75 \%)$ & $1(6.7 \%)$ & 0 \\
\hline
\end{tabular}

MV: mean value; SD: standard deviation

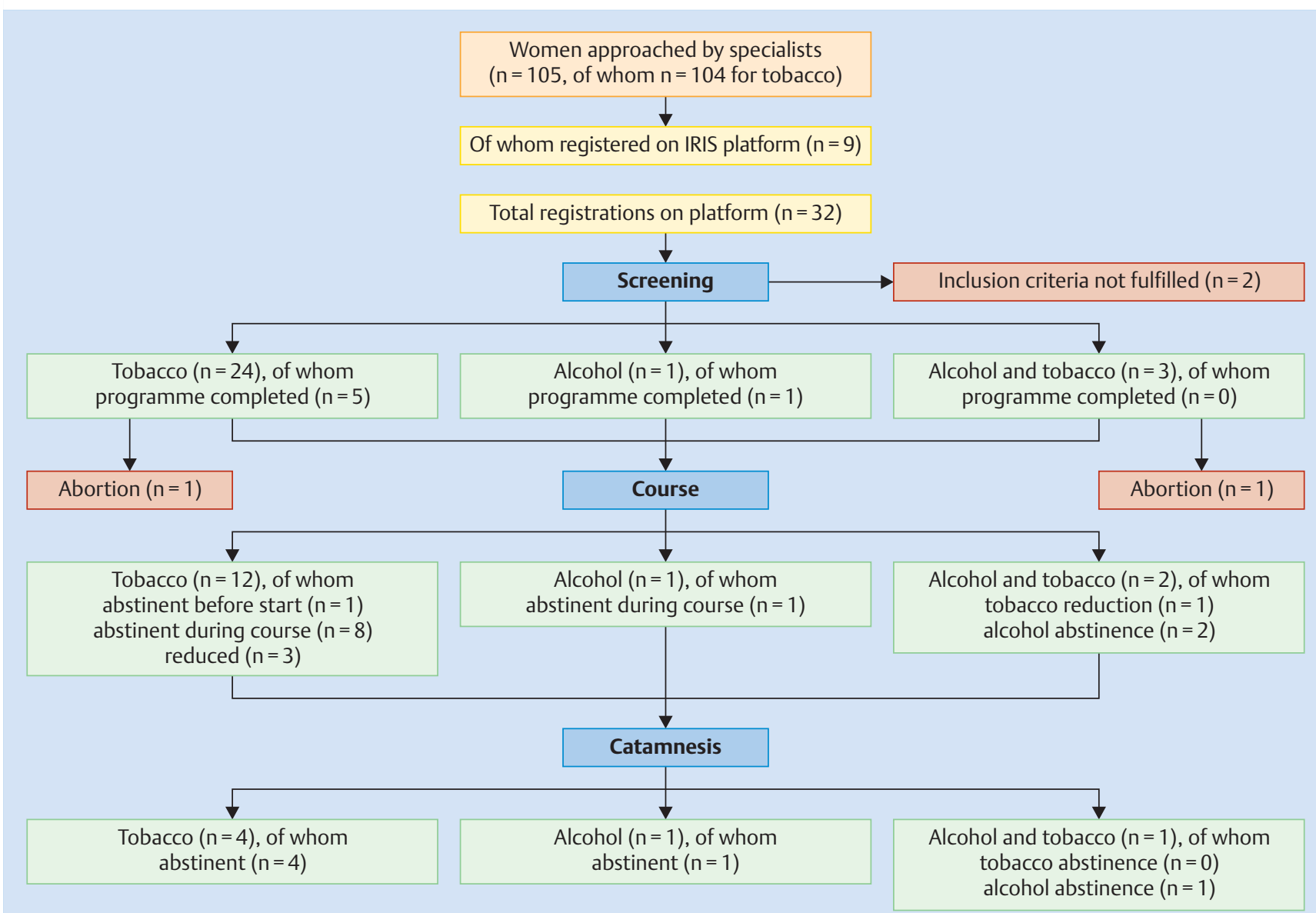

Fig. 1 Project progress IRIS-I.

Table 4 Assessment of the initiative, the eCoaching and the programme presentation in school grades ( 1 = very good, 6 = insufficient).

\begin{tabular}{|l|l|}
\hline & $\begin{array}{l}\text { Mean value } \\
\text { (n=6) }\end{array}$ \\
\hline Satisfaction with the counselling service & 2 \\
\hline How helpful was the offer? & 2.2 \\
\hline Satisfaction with the offer of eCoaching & 1.9 \\
\hline How helpful was the assistance from the eCoach? & 2 \\
\hline Satisfaction with the presentation of the programme & 2.4 \\
\hline Satisfaction with the usability of the programme & 2.3 \\
\hline
\end{tabular}

\section{Discussion}

The aim of the pilot study IRIS- 1 was to provide an internet based counselling platform for pregnant women requiring assistance to achieve tobacco and/or alcohol abstinence. Besides establishing who would use such an offer, aspects of interest were the accessibility of the participants for gynaecologists, the consumption pattern and use behaviour of the participants and their satisfaction with the offer. Study results on smoking behaviour during pregnancy allow the assumption that between 16.9 and $25 \%$ of pregnant women smoke until childbirth $[28,29]$. Prevalence fig- 
ures between $14.4 \%$ and 30 have been determined for alcohol consumption by pregnant women [30,31]. It was therefore assumed that both alcohol and tobacco consuming women could be interested in such an initiative.

32 women registered on the platform during the course of 20 weeks. A few $(n=9)$ reached the page via their gynaecologist, although these approached a large number of women $(n=105)$. Overall, considering the sociodemographic characteristics of the beneficiaries a theoretically broad accessibility of pregnant women with many different life situations, consumption profiles and pregnancy histories and social status can be assumed.

A decisive precondition for assistive measures perceived as effective and helpful for ceasing consumption during pregnancy is the accessibility of those affected. The intermediate survey among the participating gynaecologists showed a high identification rate and a good rate of approached affected persons although the recruitment rate was disappointing (8.6\%), approaches were based mainly on tobacco consumption. Smoking pregnant women therefore appear more easily identifiable, also because of their numerically greater presence. Despite the lower prevalence of alcohol consuming women it must be assumed that alcohol consuming women remain relatively frequently unrecognised. Special efforts to promote and disseminate the initiative will therefore have to be made in future. Possible approaches include improving searchability in the internet, using all media channels or involving other professions from obstetrics and counselling.

The type of initial approach to affected women also appears to be a (co-)contributory factor determining whether a pregnant woman will declare her readiness to participate in a counselling programme. There is a lack of comparative figures from similar projects which would allow a definite classification of the recruitment figures and retention rates (see below) presented here. It is to be assumed, however, that especially the women who find it difficult to renounce substance use will use the platform. The IRIS users could therefore represent a selection of the pregnant women who are either particularly motivated, health conscious and open for counselling and/or who notice having major difficulties with cessation.

Only 6 of 30 enrolled women completed the programme in the normal manner. This indicates the requirements an internet based offer has to fulfil. Suitable tools for motivation, education and support with cessation must be easily and intuitively usable and be presented as understandable, interactive and varied in order to positively influence the willingness for and the duration of participation. Recent publications which appeared after completion of the pilot phase, such as the study of Herbec et al. (2014), specify the requirements for internet based aids to cessation which are aimed specifically at pregnant women [32]. Accordingly, this should be an individualised and entertainingly designed service offering continuous support in the event of craving or relapse, clearly illustrate the benefits of the behavioural change for the baby, offer a forum for exchange with other affected persons and allow complementary personal support from experts.

Further effect factors, such as the individual stresses of pregnancy, the functionality of the consumption, the consumption and support behaviour in the social context, financial aspects or the individual degree of motivation additionally influence the utilisation of internet based counselling [33-35]. Greater attention should therefore be given to these aspects when designing programmes for the target group of pregnant women consuming addictive substances.
Some - including methodological - weaknesses of the study limit the evidential value of the results:

A comparatively small number of pregnant women were recruited, and the case numbers were correspondingly smaller during the further course (end of programme and catamnesis).

Reasons for the low registration numbers with a simultaneously high response rate from the gynaecologists could be uncertainty regarding the actual necessity to stop smoking during pregnancy and/or an insufficient awareness of the problem. Moreover, the type of approach has an influence on the willingness to participate, but also the form of presentation of the information material and the providers. The gynaecologists were invited to attend an information evening at the beginning of the study, but the procedure to be adopted for the address was not specified and was left to the physicians. Many women could have felt stigmatised by the call to use the service provided by an addiction medicine department of a psychiatric clinic. Although such reservations are decreasing in society, they are still widespread. Doubts regarding the seriousness of online counselling could negatively impact willingness to participate.

Surprising and pleasing was the high number of women who became aware of the platform by other means. Although the access route was not enquired about in this study, propagation amongst acquaintances, own researches in the internet or access via linking to the BzgA (Federal Centre for Health Education) pages are conceivable access routes, the use of which should be considered more closely in follow-up studies.

Possible reasons why not all registered persons entered the actual counselling programme after the diagnostics part were not enquired about. Conceivable are a lacking readiness to answer the questions, registrations merely from curiosity, technical problems or doubts concerning data security, no affinity for internet based offers, lacking awareness of the problem or no need for further support (since cessation merely after being approached or absence of consumption were possible).

The design of the intervention itself (anonymous, e-mail, no faceto-face contact) could be disconcerting for some individuals, but on the other hand could represent a lower inhibition threshold for claiming counselling on this (possibly taboo) issue independently of time and place. As regards the special nature of the coaching it must be considered that because of the mail contact the written language becomes the only means of communication which can be open to misunderstanding because the contents of messages can be understood differently.

The small number of fully completed programme participations could have various causes. Online interventions require a high level of personal commitment. Particularly in the new media, the attractiveness and entertainment value of the offers play a major role. The periods of use are often short. The entertaining design of a service therefore presents a great challenge and should simultaneously represent serious, effective and scientifically well-founded assistance for achieving cessation.

On the other hand, pregnant women are particularly receptive for counselling. At no point is there greater readiness to change one's own consumption habits. Many women find it much easier to cease consumption than in other phases of life, and counselling about the risks strengthens their resolve. The wish to give birth to a healthy child positively influences the cessation process as an extrinsic motivator. Since especially in the first few weeks of the programme the emphasis was on information and psychoeducation and a rapid stop on consumption, drop-outs could also be explained by rapidly achieved abstinence and thus the lacking 
need to continue participating in the programme. Conversely, it can be discussed whether it is not particularly those women who take avail of additional assistance like the IRIS programme who find achieving abstinence difficult anyway and who require continuous motivation and support which cannot be provided intensively enough by an online programme.

The abstinence rate determined in the group of smoking pregnant women (min. 18.5\% ITT) cannot be interpreted because of the very high drop-out rate. The authors assume, however, that some pregnant women rapidly became abstinent due to the registration and processing of the first subject matter and for this reason no longer became involved.

Pregnant alcohol consumers appear to be more difficult to reach in counselling. An anonymous online counselling programme could be an important addition to previous aids for this target group, but its distribution and advertising present a special challenge.

The diagnosis is based on self-disclosed information, and consequently there can be no objective and technical validation of the information, also for inclusion and exclusion criteria. Plausibility controls in questionnaire diagnosis serve to improve the data quality.

Although no representative statements can be made for the entire Federal Republic of Germany, the results of this pilot study are promising. If revision of the initiative can increase the attractiveness and benefits for the users and if the recruitment strategies are extended, internet based counselling for cessation of alcohol and tobacco could become an important supplement to the preventive and assistive activities and be of benefit to pregnant women and their (unborn) children.

Summarising an internet based service like IRIS appears to be able to reach addictive substance consuming pregnant women with different social and demographic backgrounds. The recruitment radius had a strong local limitation. The low recruitment numbers may have various causes; it also remains unanswered for what reasons participants left the programme at the different time points. The authors are convinced, however, that merely addressing pregnant women, visiting the ISIS page, the willingness to obtain information and simple registration without actually starting the programme can be important steps towards less risky alcohol or tobacco consumption behaviour. The results of this study should contribute to improving the understanding of affected persons and their life situation. The high number of smoking partners for example needs to be taken specially into account in designing a counselling initiative. Even taking into account the smaller number of affected women, however, it appears much more difficult to address alcohol consuming pregnant women than smoking pregnant women. The individual contact to the eCoach, the special feature of this programme, is considered by some observers to be a decisive factor for assistance and support, but is not utilised by everyone. The assessment of the programme presentation indicates a potential for improvement in this area. This results in considerations that, among other things, optimisation of the application and graphic interactive presentation of the IRIS programme could not only further improve the actual content but also offer the possibility to increase the adherence rates as a quality indicator in the accessibility of the target group. These ideas should be specifically implemented in the follow-on and efficacy study IRIS II. In this controlled, two-arm randomised $(1: 1)$ intervention study, $\mathrm{n}=500$ pregnant tobacco and/or alcohol consumers are to be recruited from the entire Federal Republic of Germany. The recruitment will be through multiple chan- nels (direct approach and advertising in the internet, linking with other pages) and using important multipliers, such as counselling centres or professional associations. The programme design will be comprehensively revised in content and graphic terms and interactive elements will be added. Technical optimisation will keep the number of malfunctions in programme use to a minimum, direct registrations on the page will simplify the registration process. Querying the access route provides exclusions regarding the "pathways" leading the users to the page and serves to optimise programme dissemination. Surveying the reasons for drop-out on premature termination of participation or inactivity provides important information regarding possibilities of optimisation.

\section{Conclusions for Practice \\ $\nabla$}

An internet based initiative like IRIS can be valuable as support for tobacco or alcohol consuming pregnant women. It will not be able to replace personal counselling. However, it will supplement existing offers in a novel manner, although the limitations of online counselling should be considered.

\section{Conflict of Interest}

$\nabla$

None.

\section{References}

1 Lampert T, Hrsg. DHS. Tabak - Zahlen und Fakten zum Konsum. Hamm: Jahrbuch Sucht; 2014: 64-89

2 Die Drogenbeauftragte der Bundesregierung. Drogen- und Suchtbericht 2014. Online: http://www.drogenbeauftragte.de/fileadmin/dateiendba/Presse/Downloads/Drogen-_und_Suchtbericht_2014_Gesamt_ WEB_07.pdf; last access: 26.11.2015

3 Röske K, Hannöver W, Thyrian JR et al. Welchen Umgang mit dem Thema Rauchen wünschen sich schwangere Frauen in der medizinischen Versorgung? Geburtsh Frauenheilk 2007; 67: 974-977

4 Nielsen A, Hannibal CG, Lindekilde BE et al. Maternal smoking predicts the risk of spontaneous abortion. Acta Obstet Gynecol Scand 2006; 85: 1057-1065

5 Fantuzzi G, Vaccaro V, Aggazzotti G et al. Exposure to active and passive smoking during pregnancy and severe small for gestational age at term. J Matern Fetal Neonatal Med 2008; 21: 643-647

6 Wang N, Tikellis G, Sun C et al. The effect of maternal prenatal smoking and alcohol consumption on the placenta-to-birth weight ratio. Placenta 2014; 35: 437-441

7 Iniguez C, Ballester F, Amorós R et al. Active and passive smoking during pregnancy and ultrasound measures of fetal growth in a cohort of pregnant women. J Epidemiol Community Health 2012; 66: 563-570

8 Mortensen JT, Thulstrup AM, Larsen $H$ et al. Smoking, sex of the offspring, and risk of placental abruption, placenta previa, and preeclampsia: a population-based cohort study. Acta Obstet Gynecol Scand 2001; 80: 894-898

9 Hogberg L, Cnattingius S. The influence of maternal smoking habits on the risk of subsequent stillbirth: is there a causal relation? BJOG 2007; 114: 699-704

10 Jaddoe VW, Troe EJ, Hofman A et al. Active and passive maternal smoking during pregnancy and the risks of low birthweight and preterm birth: the Generation R Study. Paediatr Perinat Epidemiol 2008; 22: 162-171

11 Metzger MJ, Halperin AC, Manhart LE et al. Association of maternal smoking during pregnancy with infant hospitalization and mortality due to infectious diseases. Pediatr Infect Dis J 2013; 32: e1-e7

12 Neuman A, Hohmann C, Orsini $N$ et al. Maternal smoking in pregnancy and asthma in preschool children: a pooled analysis of eight birth cohorts. Am J Respir Crit Care Med 2012; 186: 1037-1043 
13 Rooke S, Thorsteinsson E, Karpin A et al. Computer-delivered interventions for alcohol and tobacco use: a meta-analysis. Addiction 2010; 105: 1381-1390

14 Gainsbury S, Blaszczynski A. A systematic review of Internet-based therapy for the treatment of addictions. Clin Psychol Rev 2011; 31: 490-498

15 Civljak M, Sheikh A, Stead LF et al. Internet-based interventions for smoking cessation. Cochrane Database Syst Rev 2010; 9: CD007078

16 Cunningham J, Selby P, Kypri K et al. Access to the Internet among drinkers, smokers and illicit drugs users: Is it a barrier to the provision of interventions on the World Wide Web? Med Inform Internet Med 2006; 31: 53-58

17 Kay-Lambkin F, Baker A, Lewin T et al. Acceptability of a clinician-assisted computerized psychological intervention for comorbid mental health and substance use problems: treatment adherence data from a randomized controlled trial. J Med Internet Res 2011; 13: e11

18 Szwajcer EM, Hiddink GJ, Koelen MA et al. Nutrition-related information-seeking behaviours before and throughout the course of pregnancy: consequences for nutrition communication. Eur J Clin Nutr 2005; 59: 57-65

19 Larsson $M$. A descriptive study of the use of the Internet by women seeking pregnancy-related information. Midwifery 2009; 25: 14-20

20 Batra A, Buchkremer G. Nichtrauchen! Erfolgreich aussteigen in sechs Schritten. 4. Aufl. Stuttgart: Kohlhammer Verlag; 2013

21 Batra A, Buchkremer G. Tabakentwöhnung. Ein Leitfaden für Therapeuten. Stuttgart: Kohlhammer Verlag; 2004

22 Schober F, Peukert P, Wernz F et al. Psychoedukatives Training bei Abhängigkeitskranken. Stuttgart: Kohlhammer Verlag; 2013

23 Informationsmaterialien der Bundeszentrale für gesundheitliche Aufklärung (BZgA) zum Thema Suchtmittelkonsum und Schwangerschaft. Online: http://www.bzga.de; last access: 04.01.2016

24 Heatherton TF, Kozlowski LT, Fecker RC et al. The Fagerström Test of Nicotine Dependence: a revision of the Fagerström Tolerance Questionnaire. Br J Addict 1991; 86: 1119-1127

25 Rumpf HJ, Meyer C, Hapke U, John U. Deutsche Version des Alcohol Use Disorders Identification Test (AUDIT). In: Glöckner-Rist A, Rist F, Küfner $\mathrm{H}$, Hrsg. Elektronisches Handbuch zu Erhebungsinstrumenten im Suchtbereich (EHES). Version 2.00. Mannheim: Zentrum für Umfragen, Methoden und Analysen; 2002
26 Dilling H, Mombour W, Schmidt MH; Weltgesundheitsorganisation (WHO), Hrsg. ICD-10-Klassifikation psychischer Störungen. Kapitel V (F). 11. Aufl. Bern: Verlag Hans Huber; 2011

27 Hautzinger M, Bailer M. ADS, Allgemeine Depressions Skala. Göttingen: Beltz Test GmbH; 1992

28 Röske K, Lingnau M-L, Hannöver W et al. Prävalenz des Rauchens vor und während der Schwangerschaft - populationsbasierte Daten. Dtsch Med Wochenschr 2008; 133: 764-768

29 Bergmann RL, Bergmann KE, Schumann S et al. Smoking during pregnancy: rates, trends, risk factors. Z Geburtshilfe Neonatol 2008; 212: 80-86

30 Bergmann KE, Bergmann RL, Ellert $U$ et al. Perinatale Einflussfaktoren auf die spätere Gesundheit. Ergebnisse des Kinder- und Jugendgesundheitssurveys (KiGGS). Bundesgesundhbl Gesundheitsforsch Gesundheitsschutz 2007; 50: 670-676

31 Landgraf M, Heinen F. S3-Leitlinie Diagnostik des fetalen Alkoholsyndroms. Langfassung. AWMF-Registernummer: 022-025. Online: http://www.awmf.org/uploads/tx_szleitlinien/022-0251_S3_Fetales_ Alkohol-Syndrom_Diagnostik_Langfassung_2012-12.pdf; last access: 26.11.2015

32 Herbec A, Beard E, Brown J et al. The needs and preferences of pregnant smokers regarding tailored Internet-based smoking cessation interventions: a qualitative interview study. BMC Public Health 2014; 14: 1070

33 Gamble J, Grant J, Tsourtos G. Missed opportunities: a qualitative exploration of the experiences of smoking cessation interventions among socially disadvantaged pregnant women. Women Birth 2014; 28: 8-15

34 Flemming K, Graham H, Heirs M et al. Smoking in pregnancy: a systematic review of qualitative research of women who commence pregnancy as smokers. J Adv Nurs 2014; 69: 1023-1036

35 Flemming $K$, McCaughan D, Angus $K$ et al. Qualitative systematic review: barrieres and facilitators to smoking cessation experience by women in pregnancy and following childbirth. J Adv Nurs 2015; 71: $1210-1226$ 